\title{
Design Teaching Situation Cleverly, Strengthen the Teaching Charm in Politics Class
}

\author{
Fuying XUAN \\ Liuzhou Railway Vocational Technical College, Liuzhou, 545007, China \\ Email: xuanfy@126.com
}

Keywords: teaching situation, Politics class, teaching charm

\begin{abstract}
This is an educational art by designing teaching situations cleverly to improve teaching effectiveness. It has many advantages in politics class. Politics teachers can use a variety of materials cleverly to create teaching situation. In order to create a valuable teaching situation, teachers must master the principles of the creation of teaching situation.
\end{abstract}

\section{Introduction}

Teaching situation refers to learning situation in the class, that is, in order to achieve the established teaching objectives, according to teaching content, teacher creates a situation which is suitable for learning and acting, so students can be actively involved in teaching activities. John Dewey, American educator, once said, "The art of education is the ability to create the right situation." So learn to design teaching situation and use it in the class is one of skills for a teacher. Teachers should learn how to use this art. Now situational teaching approach in many countries and regions is very valued, which is a kind of teaching method strongly advocated by the Department of Education, regardless of the subject and age level. Ideological and political theory course is a compulsory course in colleges and universities, so we should also adopt this teaching method.

\section{The Benefits of Using Situational Teaching Method in Politics Class}

\section{Being Conductive to the Students' Attention to the Class}

Attention is one of the five basic elements of intelligence, which is to prepare the state of memory, observation, imagination and thinking. So attention is known as the gateway to the soul (Russian educator Ushinski: Attention is the only gateway to our soul, is everything in our consciousness). Ideological and political theory course is an ideological, political, theoretical courses in college and universities, and its serious and dull teaching materials make the attention of the students in the class easily be transferred, so it first need to attract the attention of students in the classroom. Using a variety of teaching materials to create a good teaching situation is regarded as a good way to improve students' attention.

\section{Being Conducive to Arouse Students' Exploration Desire}

Modern psychology argues that all human behavior is caused by a motive, and human's motivation and desire are evoked in certain situation. Single written expression in the textbooks of ideological and political theory is difficult to stimulate students' desire to explore, so it requires teachers to skillfully set the teaching situation, make the problem reside in vivid context, so that students can find the problem in context, then analyze and solve problems, make a conclusion in the end.

\section{Being Conducive to Arouse Students' Emotional Experience}

The most important teaching goal of ideological and political theory courses is not to impart knowledge, but cultivate students correct outlook of world, life, value, and moral. The students' correct ideas and concepts are in the form of participation and reflection, not in the form of theory indoctrination. Using a variety of teaching situations can not only attract the attention of students to the classroom, but also allow students to think and reflect in the teaching situation. Thinking and 
reflection must be able to arouse their intense emotional experience, so that their thoughts, ideas will change unconsciously.

\section{How to Create Teaching Situations in Ideological and Political Class}

Teaching situation can be run through the whole teaching process, which can also be used at the beginning of class, in the middle of class or at the end of class. There are so many ways to create teaching situations in ideological and political theory course.

\section{Use the Social Hot Topics to Create Teaching Situation}

Social hot topics are the topics that cause widespread concern, discuss and participate in the period of time. It is extremely realistic and generally concerned so using it to create teaching situations can stimulate students' interest in participating in the discussion. Such as this hot topic in China currently, "help or not help when seeing an old man fell on the street". This topic can create a teaching situation about "abide by the citizens' basic moral norms". In this teaching situation, show the cases of Help and their results first, and then display the cases Not Help and their results. After that, let the students discuss and answer these questions: Will you give the old man a hand? Why? This is a tradition of helping others in China. Why are there such arguments about Help or Not Help nowadays? How can we do when conscience suffered blackmail?" What morals do we call today facing the arguments about Help or Not Help? By using this similar teaching situation of moral torture, enable students to understand why we have to abide by and comply with the citizens' basic moral norms.

\section{Use the Major Social Events to Create Teaching Situation}

Major social event is a high-profile event that has a significant impact on the occurrence of a country or region. A teaching requirement in ideological and political course is close to social reality, so teachers should be adept at major social events to create teaching situations. These cases about Doctor Injuries and kills occur from time to time in recent years. By playing the video of these events, allow students to think about: what measures should the patients and their families take when they are dissatisfaction with the attitudes and behavior of the hospital and the doctors in the treatment? By thinking and analyzing, students will be able to understand the rights to take legal means, legal procedures, thereby form a legal way of thinking.

\section{Use the Famous Celebrities to Create Teaching Situation}

Famous celebrities and their quotes refer to the famous people who contribute to human development. As their quotes often contain a certain philosophy of life, using it to create the teaching situation in class, you can achieve a multiplier effect. Such as in the class of "The standards and evaluation of the value of life," teachers can cite this famous quotes: ask not what your country can do for you-ask what you can do for your country (Former U.S. President John F. Kennedy) ; If you like your own value, you must create value for the world (Goethe); As Mrs.rie, these first-class figures, their significance to the process of this time and history, in its moral quality, perhaps is bigger than purely their intellectual accomplishments ( Albert Einstein ). Let the students to realize the values in reading that the textbook convey: the standard measure of the value of life is the size of the contribution to society, and evaluating the value of a person is the unity of the material and spiritual contribution.

\section{Use the Classic Stories to Create Teaching Situation}

The classic stories refer to a model the stories with typical, elucidate and valuable reason. These stories are not only historical figures, but also allegorical stories. The story itself is more attractive than textbook theory, so using stories to create teaching situations can not only inspire students' interest in class, but also allow students to understand the truth in vivid stories. Such as in the class of abide by the basic occupation moral norms, using "the story of two horses" and "the destinies of three drywall workers" to design teaching situation, let students to think about the story of the truth, enable the students to understand the consequences of not conscientious and meticulous in work, thus establish the occupation moral sense of dedication.

Use the Small Games to Create Teaching Situation 
The games have intellectual games and active games. The biggest feature of the game is to make people enjoy a variety of emotional and psychological experience. The game can active classroom atmosphere, but also teach through lively activities in the ideological and political course. For example, during the teaching of Team Spirit, use the game of Report Number to create teaching situation: divide the class into several groups, form a circle, then count from 1 . The team count most within the prescribed time will win (once there is an error, the team will immediately stop the game). Allow students to talk about the game after finishing: how to ensure that no mistakes when reporting number? How to report the number most in the prescribed time? Students' conclusion must be: personal attention and the size of the individual voice are the keys to influence the accuracy and speed. Individuals' attention and thinking of ways to make their voice heard by their teammates are the keys to have team spirit. By this situation, students will understand building team spirit is very important.

\section{Use the Music to Create Teaching Situation}

Of all the art forms, music is the best art forms adept at expressing emotions and the most moving heartstrings. The effectiveness of education is preferably able to make people shocked. Therefore, the use of music is a way to create teaching situations which is utilized in many disciplines. Politics course is no exception. For example, in the class of patriotism, playing the famous songs sang by the famous singer, such as My Motherland, We have a Chinese name, My Chinese Heart, etc. students will have a strong patriotic infection, having a belief loving their motherland no matter where they are.

\section{Use the School-based Materials to Create Teaching Situations}

The school-based materials not only include spiritual culture, the outstanding figures etc. accumulated in the long-term process of school development, but also include the activities of some phenomena, a number of events which exist on campus, and so on. The biggest feature of school-based materials is the local resistance. Due to the student's learning and living environment closely linked with the people and things around them, the use of school history, or famous figures and the campus phenomenon can greatly cause students concern, which is a good material to create teaching situations. Such as use the photos reflecting all aspects of college life coupled with commentary to make video marked as "colorful university life". After watching, students can have a correct understanding of the university, and know how to spend their university life.

\section{The Principle of Creating Teaching Situation in Politics Class}

Teaching situation is to service for achieving teaching objectives. It must ensure that the creation of teaching situation is valuable. So teachers must master the principles of creating teaching situations to avoid some of the problems.

\section{Associate with Textbook---Avoid the Formal Teaching Situation}

Teaching situation must be closely linked to the teaching content. Teaching situation is not the outer packing of teaching. If the teaching situation created by teachers has no substantive contact with curriculum content, it may only be colorful confused situation, and students will gain nothing. Therefore, in creating teaching situation, teachers must fully understand the basis of knowledge, ability, emotional goals, then to select the best materials, and let students to accurately grasp the learning content following the provided materials.

\section{Reality---Avoid the False Teaching Situation}

Politics Teaching emphasizes on "close to students, close to the community, close to reality". Only the teaching situation from the students' real life and the social reality can arouse students' interest and encourage students to think about. So teachers should not go up from the actual teaching situation, avoid causing antagonism among students and producing a negative effect.

\section{Contain Problems---Avoid Superficial Teaching Situation}

The important objective of creating teaching situation is to let students produce desire to explore, so the creation of teaching situation is with doubt to ensure that students are in a state of mind. Thus, the teacher should not use the teaching situation which is lack of thinking value and can not cause students' thinking. Problems in teaching situation are dominant-It is also dominant that teachers ask 
questions before students enter with a teaching situation. Let students generate awareness of the issue in teaching situation, let students change their thinking and understanding after reflecting.

\section{Dissolve in Emotions---Avoid Mechanical Teaching Situation}

The valuable teaching situation must be true to life, containing both intellectual factors and nonintelligence factors, which is not a pile of simple theoretical knowledge. Soviet educator Zankov once said: once hitting the emotions and the will of students, touching students' spiritual needs, this teaching method can play a highly effective role. the most important objective in ideological and political course is to shape students' souls. Teaching situation emphasizes on arousing students' emotional reactions so that students receive spiritual shock and emotional resonance, then to establish the correct outlook of world, life, and moral.

\section{Conclusion}

Overall, teaching is a purposeful activity and the purpose of teaching can be realized by active participating of learners themselves. The best way to attract students' attention on teachers teaching is to create an emotional and spiritual teaching situation. Therefore, teachers of politics course should master the law of education, learn creating valuable teaching situations, enhance teaching attraction, and cultivate more excellent students.

\section{References}

[1] Rude Liu, Inquiry-based Learning and Teaching in Class [M] Beijing:People's Education Press, 2005-02

[2] Haoyu Zhang, Situational Teaching [J] Teachers' Forum, 2012-04

[3] Xiaoli Zhang, Situational Teaching In the Course of "Ideological and Moral Cultivation and Legal Basis " [J] Wuhan Jiaotong Polytechnic, 2008-12

[4] Fuchuan Cui, Establishment situation to improve the effectiveness of the moral character education [J] Shandong education,2009-11

[5] Yuzhen Liu, Situational Teaching Approach in the Course of "Ideological and Moral Cultivation and Legal Basis" [J] Century Bridge, 2012-11 